\title{
Variation in spring and autumn freezing resistance among and within Spanish wild populations of Castanea sativa
}

\author{
Raquel DíAZ ${ }^{1 *}, \varnothing_{\text {ystein JoHNSEN }}^{2}$, Josefa FERNÁNDEZ-LÓPEZ ${ }^{1}$ \\ ${ }^{1}$ Departamento de Producción Forestal, Centro de Investigación Forestal de Lourizán, Apdo. 127, 36080 Pontevedra, Spain \\ ${ }^{2}$ Norwegian Forest and Landscape Institute, Ås, Norway
}

Keywords:

wild chestnut /

genetic variation /

freeze testing /

phenological traits /

frost resistance

(Received 22 July 2008; accepted 28 February 2009)

\author{
Mots-clés : \\ châtaignier sauvage / \\ variation génétique / \\ test de congélation / \\ caractéristiques phénologiques / \\ résistance au gel
}

\begin{abstract}
- Genetic variation in freezing resistance was evaluated among and within six populations of Spanish wild chestnut (Castanea sativa Miller). The extent to which frost susceptibility was related to phenology and the relationship between population differentiation and climatic conditions was studied.

- Twigs were collected in March and November from saplings (5-year-old trees) of 41 openpollinated families from the six populations in a provenance-progeny test, and were subjected to artificial freezing. Damage to each twig was assessed as visible browning of bud and of stem tissues. - Population differences as regards frost damage traits were highly significant $(p<0.01)$ in both spring and autumn. Family differences within populations were low, often non-significant, and in all cases smaller than differences among populations. Population means were closely correlated with the parental drought and frost conditions. Populations originating from dry areas or from regions where frost seldom occurs were the least resistant.

- Drought is suggested to be the one of the most important selective agents that shapes population differentiation in Spanish wild chestnut, while frost may be more important in northern Spain. Phenological differences are not always good predictors of the degree of frost damage. Thus, freezing tests should be used to detect frost susceptibility in chestnuts.
\end{abstract}

Résumé - Variation de la résistance au gel au printemps et en automne entre et dans les populations espagnoles sauvages de Castanea sativa.

- La variation génétique de la résistance au gel a été évaluée entre et dans six populations espagnoles sauvages de châtaignier (Castanea sativa Miller). L'ampleur avec laquelle la sensibilité au gel est liée à la phénologie et aux relations entre la différenciation de la population et les conditions climatiques a été étudiée.

- Des rameaux ont été recueillis en mars et novembre à partir de jeunes arbres (âgés de 5 ans) de 41 familles à pollinisation libre issues de six populations en test de descendances/provenances, et ont été soumis à une congélation artificielle. Les dommages à chaque rameau ont été évalués par le brunissement visible des bourgeons et des tissus de la tige.

- Les différences entre population pour ce qui concerne les dégâts causés par le gel sont très significatifs $(p<0.01)$ au printemps et en automne. Les différences entre familles dans les populations sont faibles, souvent non significatives, et dans tous les cas plus petites que les différences parmi les populations. Les moyennes des populations sont étroitement corrélées avec les conditions de sécheresse et de gel auxquelles sont soumis les parents.Les populations originaires des régions sèches ou de régions où le gel se produit rarement sont les moins résistantes.

- On suggère que la sécheresse est l'un des plus importants agents sélectifs qui forme la différenciation dans la population espagnole de châtaigniers sauvages, tandis que le gel peut être plus important dans le nord de l'Espagne. Les différences phénologiques ne sont pas toujours de bons indices du degré de dommages par le gel. Ainsi, les essais de gel doivent être utilisés pour détecter la sensibilité au gel des châtaigniers.

\footnotetext{
*Corresponding author: rdiaz.cifal@siam-cma.org
} 


\section{INTRODUCTION}

Species of trees with wide large geographic distributions often show considerable variation in several adaptive traits, including freezing resistance (Aldrete et al., 2008). Interpopulation variation usually parallels geographic and climatic differences in physical habitats and is often characterized by extreme forms at the periphery of the range, with more or less continuous or clinal intergrading of forms between the extremes (Aldrete et al., 2008; Smithberg and Weiser, 1968). Several environmental factors, such as temperature, light and water availability, therefore interact with the genetic systems, resulting in patterns of geographic variation (Morgenstern, 1996) that are typically expressed by correlations between environmental variables and genetic source responses. Drought and frost, especially during spring, are two of the strongest environmental selective forces that cause differentiation in most temperate species (Eriksson and Ekberg, 2001; Morgenstern, 1996; Stern and Roche, 1974).

The ability of trees to grow competitively, while withstanding low temperature stresses, depends on the synchronization of growth and cold acclimation to the climatic cycle of the local environment (Hanninen et al., 1990; Linkosalo et al., 2006; Sakai and Larcher, 1987). Trees need to be able to utilize the growing season fully. Nevertheless, they need to start dehardening late enough to withstand spring frosts and commence hardening early enough to withstand autumn frosts (Saxe et al., 2001). The hardening and dehardening processes are controlled by genetically determined responses to environmental cues (Sakai and Larcher, 1987). Phenological events, such as bud burst, bud set and/or leaf fall, are often correlated with the development of cold hardiness in temperate species (Smithberg and Weiser, 1968; Weiser, 1970). Cold hardiness, however, may depend on physiological processes that occur after terminal bud formation and before bud burst, including acclimation and deacclimation (Sakai and Larcher, 1987).

The European chestnut (Castanea sativa Miller) is widely distributed across the Mediterranean region, and occurs under different climatic conditions. It is distributed as scattered populations throughout southern Europe and south-western Asia. In the Iberian peninsula, considered by several authors as a possible site of its autochthonous origin (Aira-Rodríguez and Ramil-Rego, 1995; Fineschi et al., 2000; García-Antón et al., 1990; Krebs et al., 2004), it is present as a natural or naturalised tree. The scattered distribution and isolation of populations may have resulted in differentiation among chestnut populations in adaptive traits (Ferrazzini et al., 2007), with drought and frosts being expected to be causal forces of natural selection (Fernández-López et al., 2005a). In fact, several authors have observed differentiation among populations for different adaptive traits, such as vigour, growth initiation and cessation, and drought resistance (Fernández-López et al., 2005a; 2005b; Lauteri et al., 2004; Pliura and Eriksson, 2002), and some of these authors have suggested drought as a selective force in natural selection.

Considering cold hardiness, damage produced by spring and autumn frosts is very important for any forest species in a temperate climate. Damage caused by late-spring frost can lead to failure of apical dominance, while a very harsh latespring frost or autumn frost can even cause death.

Inter-population variation in cold-hardiness has been observed in several temperate species, such as Quercus petraea (Matt) Liebl. (Deans and Harvey, 1996; Liepe, 1993), and Populus trichocarpa Torr. \& Gray (McCamant and Black, 2000), and several northern species, such as Picea abies (L.) Karst. (Johnsen and Skrøppa, 2000). However, little is known about the variation among wild chestnut populations in terms of spring and autumn cold-hardiness. Fernández-López et al. (2005a) observed significant differences among Spanish populations of wild chestnut in relation to natural spring frosts; however, there is a lack of information about autumn cold hardiness and intra-stand variation for spring frost.

Artificial freeze testing under controlled conditions is an excellent tool for studying variation in cold-hardiness. Several authors have used this for different species (Fernandez et al., 2007; Jensen and Deans, 2004; Johnsen, 1989; Tsarouhas et al., 2000). The visual scoring of damage in different tissues, i.e. bud and stem tissues, is a valuable method for detecting frost susceptibility (Aitken and Adams, 1996; Jensen and Deans, 2004).

The main objectives of the present study were: (1) to study the genetic variation among and within Spanish wild chestnut populations considering susceptibility to spring and autumn frosts; (2) to estimate the relationships between the susceptibility of different tissues and between different susceptibilities and bud phenology; and (3) to evaluate the possible influence of the geoclimatic origin of populations on the results obtained.

\section{MATERIALS AND METHODS}

\subsection{Plant material and test site}

Six natural wild chestnut populations growing in Spain between 39.5 to $43.3{ }^{\circ} \mathrm{N}$, and 5.3 to $8.4^{\circ} \mathrm{W}$, and at 100 to $950 \mathrm{~m}$ a.s.l., were chosen, with the aim of studying population variation (Fig.1). These natural populations were identified as being without any signs of recent human influence, such as grafting, and because they represented the Spanish area of distribution of Castanea sativa, and included extreme populations as regards climate (Tab. I) and geographic distance. The high variability of these populations and the absence of any effects of management have recently been demonstrated by use of molecular markers (Fernández-López, pers. comm.). Considering climate variables, the drought index $(\mathrm{A})^{1}$ varied between a time span of 0 months (for population 5) and 3.8 months (for population 3). The number of days below $0{ }^{\circ} \mathrm{C}$ in spring (ND0S, where spring comprises April, May and June) was between 0.1 (population 4) and 16.8

\footnotetext{
${ }^{1}$ Drought index (A) is defined here as the time span, measured in months, during which the curve of the monthly mean values lies above the monthly precipitation curve, $p_{i}$, in an ombro-thermal Gaussen-type graph (months on the $X$-axis and temperature and precipitation on the $Y$-axis, so that the values of $p$ are the same height as the expression of temperature in degrees of half their value). This factor correlates well with the actual configuration of water deficits and approximately implies the condition $2 t_{i} \geqslant p_{i}$.
} 


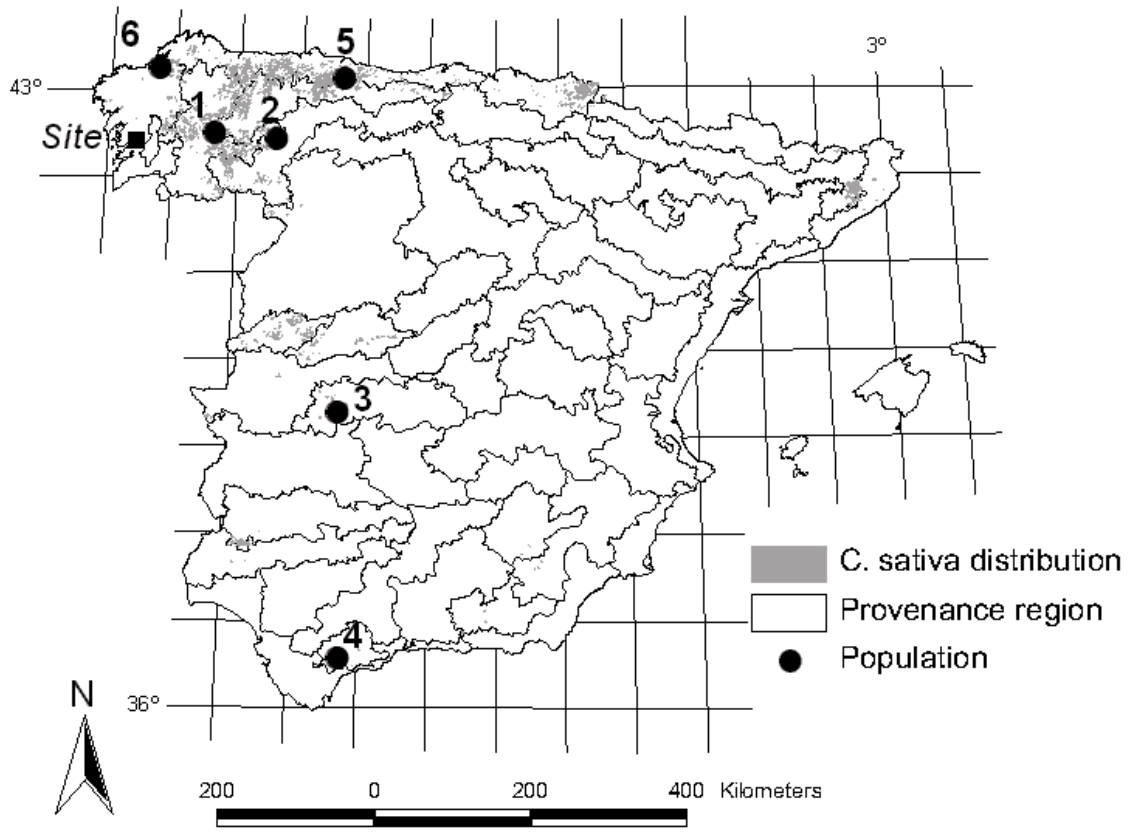

Figure 1. Locations of the places of origin of the six wild chestnut populations studied.

Table I. Climatic parameters at the places of origin of the six studied populations. Trait codes and dimensions are shown in parentheses.

\begin{tabular}{|c|c|c|c|c|c|c|}
\hline \multirow{2}{*}{ Climatic parameter } & \multicolumn{6}{|c|}{ Population } \\
\hline & 1 & 2 & 3 & 4 & 5 & 6 \\
\hline Mean of max. temp. in month with highest mean $\left(\mathrm{TMMC},{ }^{\circ} \mathrm{C}\right)$ & 25.8 & 26.6 & 26.5 & 26.4 & 22.9 & 24.5 \\
\hline Absolute maximum temperature $\left(\mathrm{AMT},{ }^{\circ} \mathrm{C}\right)$ & 34.8 & 38.3 & 37.7 & 38.3 & 36.7 & 36.5 \\
\hline Absolute minimum temperature $\left(\mathrm{F},{ }^{\circ} \mathrm{C}\right)$ & -4.2 & -12.5 & -9.3 & -0.7 & -9.8 & -9.5 \\
\hline Min. monthly summer precipitation (PE, mm) & 19.0 & 16.0 & 3.0 & 0.0 & 42.0 & 22.0 \\
\hline No. days with $T<0{ }^{\circ} \mathrm{C}$ in autumn (ND0A, day) & 4.1 & 10.8 & 0.5 & 0.3 & 1.0 & 0.7 \\
\hline
\end{tabular}

* Drought index $(A)$ : time span, measured in months, during which the curve of the monthly mean values lies above the monthly precipitation curve, $p_{i}$, in an ombro-thermal Gaussen-type graph (months on the $X$-axis and temperature and precipitation on the $Y$-axis, so that the values of $p$ are the same height as the expression of temperature in degrees of half their value). This factor correlates well with the actual configuration of water deficits and approximately implies the condition $2 t_{i} \geqslant p_{i}$.

(population 2) days, while the number of days below $0{ }^{\circ} \mathrm{C}$ in autumn (ND0A, where autumn comprises September, October and November) varied between 0.3 (population 4) and 10.8 (population 2) days.

Seeds from open pollination in 2001 were collected from randomly selected mother trees within each of these populations. Seed lots from each tree were kept and sown separately, and seedlings from each tree were considered as an open-pollinated family. A common garden provenance-progeny test was planted at Rebordelo (Pontevedra, northwestern Spain) in 2002 with the seedlings obtained from these open-pollinated families. The experimental design was a randomized complete block design, with 20 blocks, 54 open-pollinated families (originating from the six chosen populations) and one-tree plots. The number of separate open-pollinated families within each population varied between 5 and 14. Some families were not represented in each block because of poor germination (missing values). For this reason, the total number of plants was 838 (767 still alive).

\subsection{Artificial freeze tests}

Two freeze tests were conducted on twigs collected from the individual chestnut saplings growing in the Rebordelo provenanceprogeny test. Twigs from 545 individuals (5 years old) of the total of 767 at Rebordelo were included in the freeze tests twice, once in spring (14th March) and once in autumn (13th November) 2006. The 545 individuals belonged to 41 families of the six studied populations.

For each freeze test, five twigs, 15-20 cm long, were collected from lateral branches of chestnuts in Rebordelo. All twigs were collected on a single day, placed in plastic bags, and transported to the laboratory in boxes filled with ice. After transportation, the twigs were stored in a refrigerator for a maximum of 3 days before freeze testing. Four twigs were selected at random for the freeze tests and one twig was used as an unfrozen control. The four selected twigs were subjected to four different freezing test temperatures $(-7,-10$, 
-12 and $-15^{\circ} \mathrm{C}$ in both freeze tests). The four temperatures chosen for each freeze test were determined from preliminary tests on twigs collected two weeks before the main freeze test; the twigs were from 12 randomly chosen trees. Results from the wide range of temperatures ( -6.5 to $-14.5{ }^{\circ} \mathrm{C}$ in spring, and -4.2 to $-17.6{ }^{\circ} \mathrm{C}$ in autumn) were used for selection of those temperatures where maximal variation in freezing resistance was found (see section "Statistical analysis").

Twigs were placed in plug trays in a complete randomized block design, with the 41 families (5-8 families per population), 15 blocks and one-tree plots per assayed temperature. The trays with the test twigs were sprayed with demineralized water and placed in a freezing chamber. The trays with the control twigs were left in the refrigerator. In both freeze tests (spring and autumn), the starting temperature $\left(5{ }^{\circ} \mathrm{C}\right)$ was maintained for at least $7 \mathrm{~h}$, and the temperature was then decreased at a rate of $2{ }^{\circ} \mathrm{C} / \mathrm{h}$. Plug trays were removed from the freezing chamber as the predefined sampling temperatures were reached, and then stored in a fridge at $2{ }^{\circ} \mathrm{C}$ for at least $20 \mathrm{~h}$. All the trays (including unfrozen controls) were then maintained in a greenhouse at $20{ }^{\circ} \mathrm{C}$ and $90 \%$ relative humidity (fog) for three and four weeks for the spring and autumn tests, respectively. After this period of time, the assayed twigs were evaluated by visual scoring of stem and bud tissues for cold damage.

\subsection{Assessments}

Visual discoloration is an effective indicator of loss of tissue viability following freezing (Calkins and Swanson, 1990) and was used in the present study to assess cold damage to stems and buds. The stems and buds were cut lengthwise and each sample was scored visually. Damage to the stem or buds was indicated by browning or yellowing of normally greenish tissues, and evaluation was always made in relation to the fresh green colour of the unfrozen controls that underwent the same procedure, except for freezing. Stem damage $(\mathrm{SD})$ was classified on a six-point scale $(0=$ green stem without damage as for the controls, $1=$ yellowish stem, $2=$ yellowish to light brown stem, $3=$ light brown stem, $4=$ less than $50 \%$ of the twig completely brown, $5=$ more than $50 \%$ of the twig completely brown), and terminal bud damage (TB) was classified on a 3-point scale $(0=$ completely green terminal bud as for the controls, $1=$ partially brown terminal bud, 2 = dead terminal bud). Lateral buds were also scored on a two-point scale $(0=$ alive as for the controls, $1=$ dead, dried out with brown colour) and the dead lateral bud percentage (DBP) was estimated for each twig, as the proportion of dead lateral buds in the total number of lateral buds, expressed as a percentage. All scoring was carried out by two researchers, and all samples from the same replication were scored by the same person.

Some field traits were also assessed in the Rebordelo provenanceprogeny test. They were assessed on all the 767 live plants in the provenance-progeny test, not only on those trees used for the freeze testing (545). Bud burst and leaf fall were recorded in spring and autumn 2006, respectively. An eight-point scale was used for bud burst $(1=$ dormant bud to $8=$ shoot length longer than $10 \mathrm{~cm}$ ) (FernándezLópez et al., 2005a), and a 5-point scale for leaf fall (1 = no leaf has fallen to $5=$ all leaves have fallen). Both field traits were assessed twice.

Geographic (latitude, longitude and altitude) and climatic data were determined for the place of origin of each population. A total of 33 climatic variables were considered, all of which were related to precipitation, temperature, drought, thermal oscillation, and number of days with temperatures below $0{ }^{\circ} \mathrm{C}$ in different periods of the year.
Fifteen variables were taken from Allué (1990) and the others were determined with meteorological data from different climatic stations of the Spanish Meteorological Institute. All climatic parameters were mean values calculated from at least ten years of data.

\subsection{Statistical analysis}

For each injury trait, the mean value of the data, corresponding to the two temperatures for which the highest coefficient of variation per block was observed, was used in the analyses. In general, data corresponding to the two highest temperatures $\left(-7\right.$ and $\left.-10^{\circ} \mathrm{C}\right)$ were used in the spring test, while data corresponding to the two intermediate temperatures $\left(-10\right.$ and $\left.-12{ }^{\circ} \mathrm{C}\right)$ were used in the autumn test. For the field variables, we used score data recorded on a single day, selecting the date with the maximum coefficient of variation (Baliuckas et al., 1999; Jermstad et al., 2001).

All statistical analyses were performed with SAS 8.02 (SAS, 1999). Prior to the analyses, all traits were transformed per block by the use of a normal score transformation, as they were all categorical traits with an underlying increase in severity of the injury or advance in development from one class to the next (Johnsen et al., 2005). The transformations restored normality and homogeneity of variances to the distributions. The traits were coded and numbered according to their nature: bud burst in 2006 (BB06), leaf fall in 2006 (LF06), terminal bud injury in spring (TB1) and autumn (TB2), dead lateral bud percentage in spring (DBP1) and autumn (DBP2) and stem damage in spring (SD1) and autumn (SD2).

Variance components (and the population least square means) were estimated with the MIXED procedure (including the Lsmeans statement in the procedure) of the SAS/STAT software, which uses the restricted maximum likelihood (REML) algorithm (SAS, 1999). The following mixed model was used:

$$
X_{k(i j)}=\mu+P_{i}+F(P)_{j(i)}+\varepsilon_{k(i j)}
$$

where $X_{k(i j)}$ is the value of the response variable measured on the $k$ th tree of the $j$ th family within the $i$ th population, $\mu$ is the overall mean, $P_{i}$ and $F(P)_{j(i)}$, are the effects of the $i$ th population $(i=1$ to 6$)$ and the $j$ th family within the $i$ th population ( $j=1$ to 8 ), respectively, and $\varepsilon_{k(i j)}$ is the residual variation affecting the $k$ th tree of the $j$ th family of the $i$ th population. All factors were considered random, except population. No significant interaction between block and population was found, and hence this term was excluded from the model.

Population least square means were also estimated for the original variables with the Proc Mixed procedure in order to convert the estimated differences to mean percentages (or class means).

Individual narrow-sense heritability $\left(h_{i}^{2}\right)$ and family heritability $\left(h_{f}^{2}\right)$ were estimated as follows:

$$
\begin{gathered}
h_{i}^{2}=\frac{3 \cdot \sigma_{F(P)}^{2}}{\sigma_{F(P)}^{2}+\sigma_{e}^{2}} \\
h_{f}^{2}=\frac{\sigma_{F(P)}^{2}}{\sigma_{F(P)}^{2}+\sigma_{e}^{2} / n b}
\end{gathered}
$$

where $\sigma_{F(P)}^{2}$ is the family within population variance, $\sigma_{e}^{2}$ is the residual variance, and $b$ and $n$ are the number of blocks and the harmonic mean of the number of trees per plot, respectively. A coefficient of 3 , rather than 4, was used to estimate the individual heritability, because all families were derived from open pollination (Squillace, 1974). The 
Table II. Basic statistics, variance components, significance levels and heritability estimates $\left(h_{i}^{2}\right.$ and $\left.h_{f}^{2}\right)$ for the spring and autumn frost damage traits. Population was considered as a fixed factor.

\begin{tabular}{|c|c|c|c|c|c|c|c|c|c|}
\hline & \multirow[t]{2}{*}{ Mean } & \multirow[t]{2}{*}{ Std } & \multicolumn{2}{|c|}{ Population } & \multicolumn{3}{|c|}{ Variance comp. } & \multirow{2}{*}{$h_{i}^{2}$ (s.e.) } & \multirow{2}{*}{$h_{f}^{2}$ (s.e.) } \\
\hline & & & $F^{a}$ & $\operatorname{Pr}>F$ & Fam & & Error & & \\
\hline \multicolumn{10}{|l|}{ Field traits } \\
\hline Bud burst in spring 2006 (BB06) & 3.2 & 1.26 & 66.59 & $* * *$ & 0.03 & $* *$ & 0.38 & $0.19(0.03)$ & $0.49(0.10)$ \\
\hline Leaf fall in autumn 2006 (LF06) & 4.1 & 1.29 & 24.10 & $* * *$ & 0.03 & $*$ & 0.49 & $0.17(0.02)$ & $0.47(0.09)$ \\
\hline \multicolumn{10}{|l|}{ Injury traits } \\
\hline Stem damage in spring (SD1) & 1.9 & 1.09 & 20.10 & $* * *$ & 0.01 & & 0.72 & & \\
\hline Terminal bud damage in spring (TB1) & 1.0 & 1.00 & 29.45 & $* * *$ & 0.04 & $*$ & 0.46 & $0.22(0.03)$ & $0.51(0.10)$ \\
\hline Dead lateral bud \% in spring (DBP1) & 39.3 & 34.90 & 19.19 & $* * *$ & 0.05 & $*$ & 0.61 & $0.21(0.03)$ & $0.50(0.10)$ \\
\hline Stem damage in autumn (SD2) & 2.0 & 1.00 & 4.23 & $* *$ & 0.00 & & 0.80 & & \\
\hline Terminal bud damage in autumn (TB2) & 1.0 & 1.00 & 5.10 & $* *$ & 0.00 & & 0.56 & & \\
\hline Dead lateral bud \% in autumn (DBP2) & 38.1 & 40.26 & 4.64 & $* *$ & 0.02 & & 0.67 & & \\
\hline
\end{tabular}

${ }^{a} \mathrm{~F}_{5,47}$ for field traits, $F_{5,35}$ for injury traits.

Significance levels: *** $P<0.001 ; * * P<0.01 ; * P<0.05$.

Table III. Differences among and within populations for the studied traits. Differences among populations were estimated from the Lsmeans of the populations (as population was considered as a fixed effect), whereas differences within populations were estimated from the Blups of the families. All differences (= maximum - minimum) were estimated with the transformed variables (normal score).

\begin{tabular}{lcc}
\hline & $\begin{array}{c}\text { Among } \\
\text { populations }\end{array}$ & $\begin{array}{c}\text { Within } \\
\text { populations }\end{array}$ \\
\hline Field traits & & \\
Bud burst in 2006 (BB06) & 1.43 & 0.32 \\
Leaf fall in 2006 (LF06) & 0.98 & 0.32 \\
Injury traits & & \\
Stem damage in spring (SD1) & 1.20 & 0.17 \\
Terminal bud damage in spring (TB1) & 1.40 & 0.54 \\
Dead lateral bud percentage in spring (DBP1) & 1.35 & 0.66 \\
Stem damage in autumn (SD2) & 0.54 & 0.05 \\
Terminal bud damage in autumn (TB2) & 0.57 & 0.06 \\
Dead lateral bud percentage in autumn (DBP2) & 0.65 & 0.30 \\
\hline
\end{tabular}

standard error of the heritabilities $\left(s e\left(h_{i}^{2}\right)\right.$ and $\left.s e\left(h_{f}^{2}\right)\right)$ was estimated as reported by Lynch and Walsh (1998, p. 568).

The difference among populations for each studied trait was estimated by subtracting the minimum from the maximum population Lsmean. The mean value of the differences among families within populations was also estimated. Differences within each population were calculated by subtracting the minimum from the maximum family Blup estimate. Both Lsmean and Blup were estimated from the nscore transformed variables.

The Pearson phenotypic correlation coefficients of the mean values per family and of the Lsmean values per population were computed by the SAS 8.0 Proc CORR procedure (SAS, 1999) to determine the extent of relationships between all traits.

Analyses of variance with individual-tree phenology data as covariates were also performed to determine whether differences in susceptibility were only due to differences in phenology, or whether there were other factors involved.

The relationship between injury traits and the geoclimatic variables at the place of origin was analysed by Pearson correlation on a population mean basis $\left(r_{P}\right)$.

\section{RESULTS}

\subsection{Genetic variation among and within populations}

Significant differences among populations were found for both damage and field traits (Tab. II). The family (within population) variance was only significant for the field traits (BB06 and LF06) and for the damage to bud tissue in spring (TB1 and DBP1), but not for the other damage traits (SD1, TB2, DBP2 and SD2). The difference among populations was greater than the differences among families within populations for all the studied traits (Tab. III). When differences among families within populations were significant, heritability estimates were high at the family level $(0.47-0.51)$ but low to moderate for individual trees $(0.17-0.22)$.

Taking into account spring frost damage, trees from populations 2, 4 and 3, especially those from 2 and 4, were most damaged, while trees from population 5 were most resistant (Figs. 2b-2d). However, different responses to autumn frost damage were observed in the different tissues (bud and stem tissues). For bud tissues, trees from populations 4, 2 and 5, especially from population 4 , were most damaged, while trees from population 1 were most resistant (Figs. 2f, 2g). For the stem tissue, trees from population 2 were the most damaged, while those from populations 5 and 6 were the most resistant (Fig. 2h).

\subsection{Relationship between different tissue injury traits}

At the individual level, phenotypic correlations between different injury traits were high in both spring and autumn $(r \geqslant 0.35, p<0.001$, Tab. IV). Stem damage in autumn was also correlated with spring damage traits $(r \geqslant 0.11, p<0.05)$. However, bud tissue damage in autumn (TB2 and DBP2) was not related to any of the spring damage traits.

At the population level, correlations between different damage traits were high for spring frost injury $(r \geqslant 0.98, p<$ 0.001 , Tab. IV). For autumn frost, bud tissue damage traits were highly correlated $(r=0.93, p<0.01)$, but they were not 
(a) Bud burst (BB06)

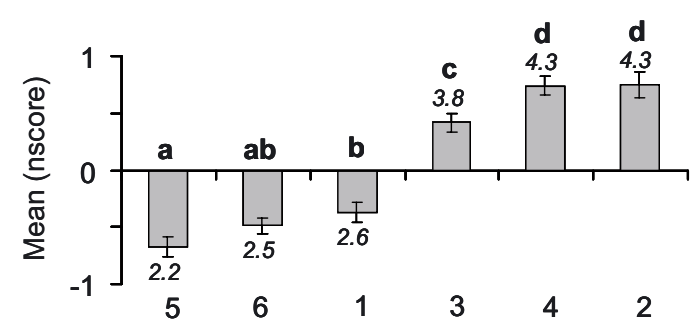

(b) Terminal bud damage in spring (TB1)

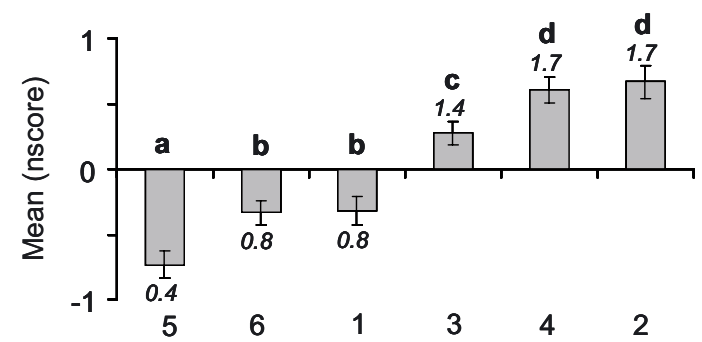

(c) Dead bud percentage in spring (DBP1)

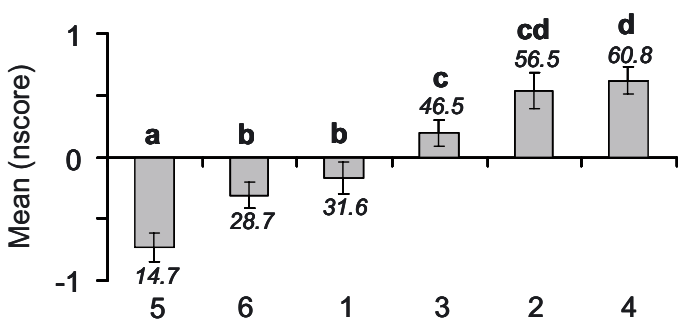

(d) Stem damage in spring (SD1)

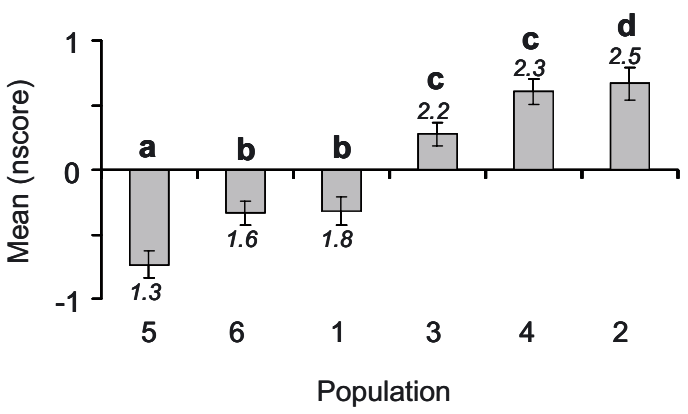

(e) Leaf fall (LF06)

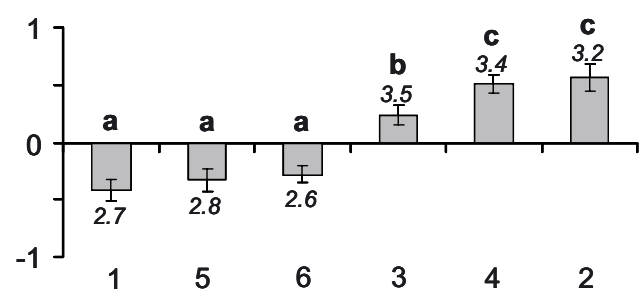

(f) Terminal bud damage in autumn (TB2)

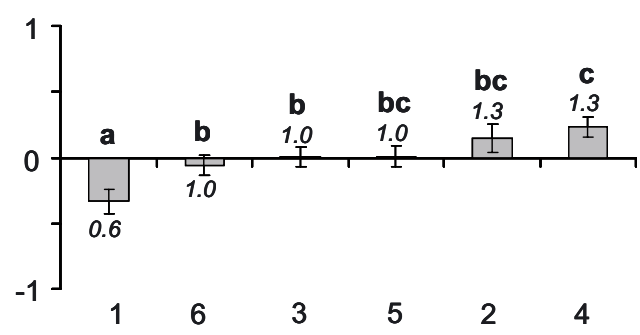

(g) Dead bud percentage in autumn (DBP2)

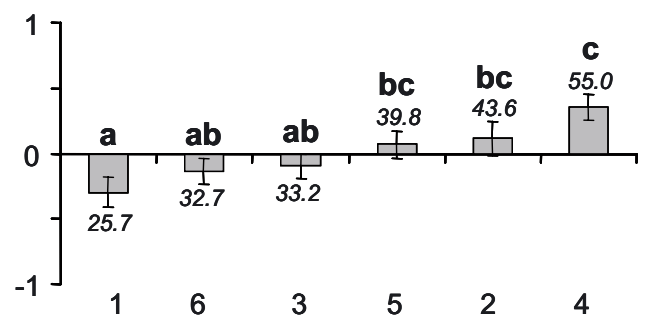

(h) Stem damage in autumn (SD2)

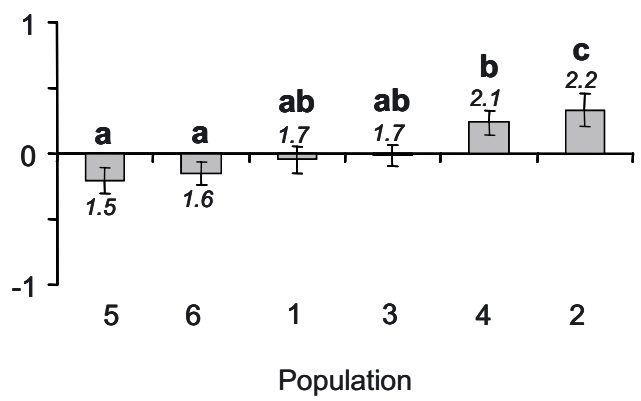

Figure 2. Differences among populations for the damage traits obtained from the mixed models without covariates. Bar graphs show least square mean values (Lsmeans) for the studied populations and vertical lines represent standard errors. Numbers associated with bars are the original least square class means from the approximate analyses of the original variables. Different letters denote significant differences $(p<0.05)$.

correlated with stem damage. The populations showing most stem damage in autumn were those that showed the greatest degree of spring frost damage $(r \geqslant 0.93, p<0.01)$.

\subsection{Relationship with bud burst and leaf fall}

At the individual level, the trees with earliest bud burst were those that showed the earliest leaf fall and the greatest degree of spring frost damage ( $r \geqslant 0.34, p<0.001$, Tab. IV). No relationship was found between bud burst and autumn frost damage at the individual level. The trees with the earliest leaf fall were those that showed the greatest degree of spring and autumn frost damage $(r \geqslant 0.15, p<0.001)$.

At the population level, the populations with earliest bud burst were those with the earliest leaf fall, with the most severe spring frost injuries in different tissues and with the largest 
Table IV. Pearson's correlation coefficients -based on individual values (above diagonal, $N=545$ ) and on population Lsmeans (below diagonal, $N=6)$ - between the different field and frost damage traits. Only significant coefficients $(p<0.05)$ are shown.

\begin{tabular}{|c|c|c|c|c|c|c|c|c|c|c|c|c|c|c|c|c|}
\hline \multirow[b]{3}{*}{ BB06 } & \multicolumn{4}{|c|}{ Field traits ${ }^{\mathrm{a}}$} & \multicolumn{12}{|c|}{ Damage traits ${ }^{b}$} \\
\hline & \multicolumn{2}{|c|}{ BB06 } & \multicolumn{2}{|c|}{ LF06 } & \multicolumn{2}{|c|}{ SD1 } & \multicolumn{2}{|c|}{ TB1 } & \multicolumn{2}{|c|}{ DBP1 } & \multicolumn{2}{|c|}{ SD2 } & \multicolumn{2}{|c|}{ TB2 } & \multicolumn{2}{|c|}{ DBP2 } \\
\hline & & & 0.34 & $* * *$ & 0.51 & $* * *$ & 0.65 & $* * *$ & 0.61 & $* * *$ & & & & & & \\
\hline LF06 & 0.97 & $* *$ & & & 0.17 & $* * *$ & 0.34 & $* * *$ & 0.27 & $* * *$ & 0.15 & $* * *$ & 0.17 & $* * *$ & 0.16 & $* * *$ \\
\hline SD1 & 0.98 & $* * *$ & 0.93 & $* *$ & & & 0.51 & $* * *$ & 0.59 & $* * *$ & 0.14 & $* *$ & & & & \\
\hline TB1 & 0.99 & $* * *$ & 0.96 & $* *$ & 0.99 & $* * *$ & & & 0.69 & $* * *$ & 0.11 & $*$ & & & & \\
\hline DBP1 & 0.97 & $* *$ & 0.91 & $*$ & 0.98 & $* * *$ & 0.99 & $* * *$ & & & 0.11 & * & & & & \\
\hline SD2 & 0.92 & $* *$ & 0.90 & $*$ & 0.95 & $* *$ & 0.94 & $* *$ & 0.93 & $* *$ & & & 0.35 & $* * *$ & 0.54 & $* * *$ \\
\hline TB2 & & & 0.82 & $*$ & & & & & & & & & & & 0.60 & $* * *$ \\
\hline DBP2 & & & & & & & & & & & & & 0.93 & $* *$ & & \\
\hline
\end{tabular}

${ }^{a}$ BB06, Bud burst in spring 2006; LF06, Leaf fall in autumn 2006.

b SD1 and SD2: Spring and autumn stem damage, respectively; TB1 and TB2: Spring and autumn damage on terminal bud, respectively; DBP1 and DBP2: Spring and autumn damage on lateral buds (in percentage), respectively.

Significance levels. *** $P<0.001 ; * * P<0.01 ; * P<0.05$.

Table V. Variance components and significance levels for the spring and autumn frost damage traits obtained from the mixed models with respectively bud burst and leaf fall as covariates. Population was considered as a fixed factor.

\begin{tabular}{|c|c|c|c|c|c|c|c|}
\hline \multirow[b]{3}{*}{ Variable } & \multicolumn{4}{|c|}{ Fixed factors } & \multirow{2}{*}{\multicolumn{3}{|c|}{ Variance components }} \\
\hline & \multicolumn{2}{|c|}{ Covariance } & \multicolumn{2}{|c|}{ Provenance } & & & \\
\hline & $F$ & $\operatorname{Pr}>F$ & $F_{5,35}$ & $\operatorname{Pr}>F$ & Family $(P)$ & $\operatorname{Pr}>F$ & Error \\
\hline Stem damage in spring (SD1) & 69.22 & $* * *$ & 2.93 & $*$ & 0.01 & & 0.64 \\
\hline Terminal bud damage in spring (TB1) & 119.87 & $* * *$ & 10.05 & $* * *$ & 0.01 & & 0.37 \\
\hline Dead lateral bud \% in spring (DBP1) & 118.7 & $* * *$ & 3.57 & $*$ & 0.02 & & 0.5 \\
\hline Stem damage in autumn (SD2) & 3.53 & & 2.41 & $\mathrm{a}$ & 0.00 & & 0.79 \\
\hline Terminal bud damage in autumn (TB2) & 4.97 & $*$ & 2.97 & $*$ & 0.01 & & 0.55 \\
\hline Dead lateral bud \% in autumn (DBP2) & 4.68 & $*$ & 3.38 & $*$ & 0.02 & & 0.66 \\
\hline
\end{tabular}

Significance levels. $* * * P<0.001 ; * * P<0.01 ; * P<0.05 ;{ }^{a} P<0.06$.

autumn frost injury in the stem $(r \geqslant 0.92, p<0.01$, Tab. IV). The earliest leaf-fall populations were those with the most spring and autumn frost damage, except in lateral buds in autumn $(r \geqslant 0.82, p<0.05)$.

In the analysis of spring and autumn damage data with bud burst and leaf fall as covariates, respectively, the error variances were reduced and all family variances became nonsignificant (Tab. V). However, differences among populations remained highly significant in these analyses. The differences among populations for the damage traits when the covariates were included in the model are shown in Figure 3. As regards spring damage traits, population 5 still differed significantly from populations 2 and 4 . For autumn damage on bud tissues, trees from populations 4,2 and 5, especially from population 4 , were still the most damaged, while population 1 was the most resistant. For autumn damage to stem tissue, trees from populations 2 and 4 showed the greatest degree of damage, while those from population 5 were still the most cold tolerant, and the differences were highly significant.

\subsection{Geographic variation}

Pearson's correlations between the Lsmeans per population of the studied traits and the geoclimatic data at population origin were estimated (Tab. VI). The most important relationships are shown in Figures 4 and 5.
The mean of the maxima in the month with the highest mean temperature (TMMC) and the drought index $(A)$ were positively correlated with bud burst and spring frost damage (Tab. VI all populations and Figs. $4 a-4 c)$. The minimum monthly summertime precipitation (PE) was also significantly but negatively correlated with bud tissue damage in spring (Tab. VI). The absolute maximum temperature (AMT) was positively correlated with leaf fall and bud tissue damage in autumn (Tab. VI and Figs. 4d-4f). However, none of the geoclimatic parameters considered (a total of 33, see Materials and Methods) were significantly correlated with stem damage in autumn. The highest correlation was with the mean of the maxima in the month with the highest mean temperature (TMMC) $(r=0.78, p<0.07)$. No correlation between the freezing damage traits (i.e. cold stress responses) and the cold stress parameters (TMMF, F, NDOS and ND0A) was found.

When only the four northern populations were analysed (1, 2, 5 and 6), different relationships were observed (Tab. VI and Fig. 5). In this case, all variables were related to frost climatic parameters. Both field variables were related to the number of days with mean temperature below $0{ }^{\circ} \mathrm{C}$ during spring. Spring frost damage was related to the number of days below $0{ }^{\circ} \mathrm{C}$ during spring $\left(r^{2} \geq 0.96, p<0.05\right.$ ) (Fig. 5a), and autumn frost damage was related to the mean of the temperature minima in the month with the lowest mean $\left(r^{2} \leq-0.96\right.$, $p<0.05$ ) when working with bud tissues (Fig. 5b), and to 
(a) Terminal bud damage in spring (TB1)

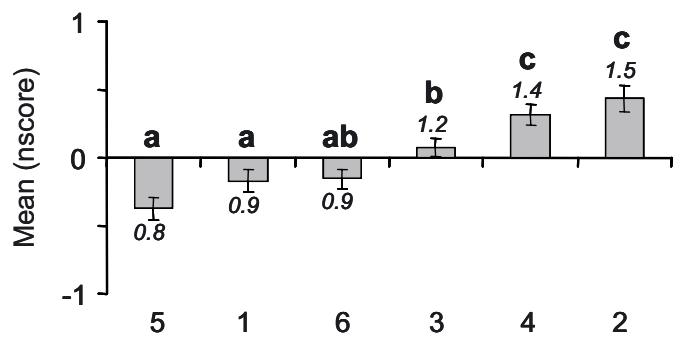

(b) Dead bud percentage in spring (DBP1)

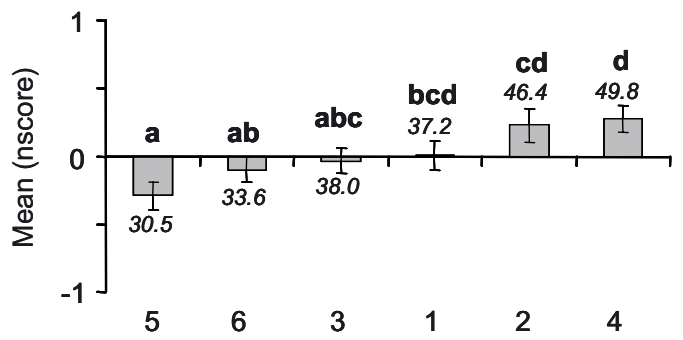

(c) Stem damage in spring (SD1)

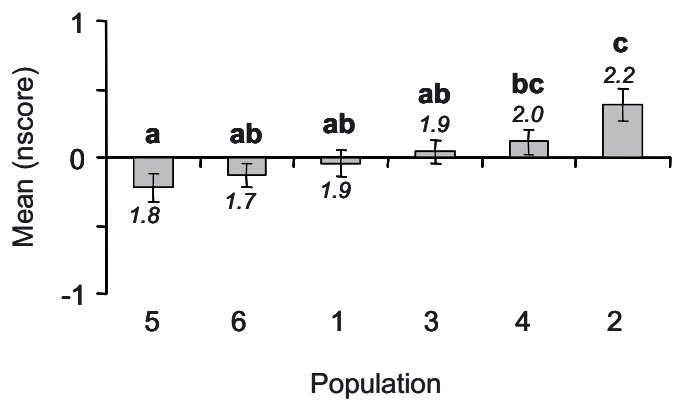

(d) Terminal bud damage in autumn (TB2)

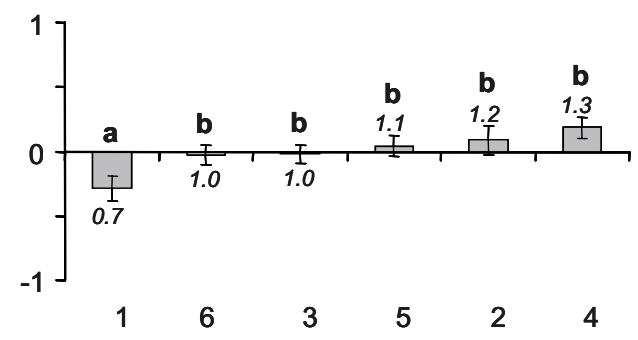

(e) Dead bud percentage in autumn (DBP2)

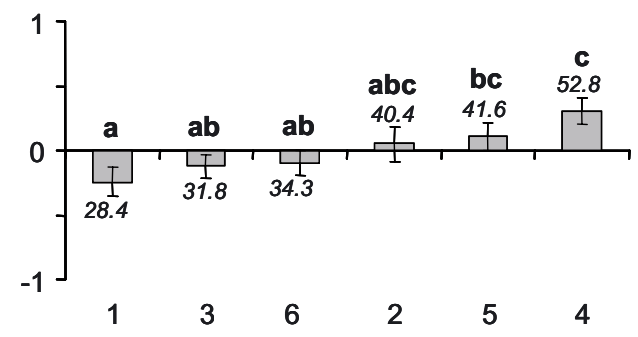

(f) Stem damage in autumn (SD2)

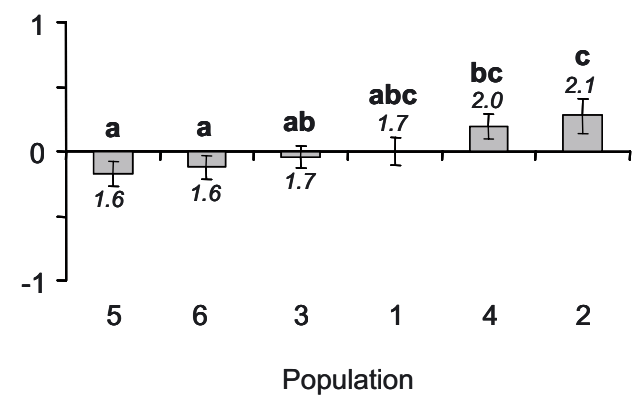

Figure 3. Differences among populations for the damage traits obtained from the mixed models with bud burst and leaf fall as covariate for spring and autumn damage traits, respectively. Bar graphs show least square mean values (Lsmeans) for the studied populations and vertical lines represent standard errors. Numbers associated with bars are the original least square class means from the approximate analyses of the original variables. Different letters denote significant differences $(p<0.05)$.

the number of days below $0{ }^{\circ} \mathrm{C}$ during spring and autumn $\left(r^{2}=0.99, p<0.01\right)$ when considering stem tissue (Fig. 5 c).

\section{DISCUSSION}

Several authors have found differences among wild chestnut populations for adaptive traits, such as height (FernándezLópez et al., 2005a; 2005b; Pliura and Eriksson, 2002), bud burst and bud set (Fernández-López et al., 2005a; 2005b), carbon isotope discrimination (related to drought adaptation) (Lauteri et al., 2004), and several dry weight traits (Pliura and Eriksson, 2002). Fernández-López et al. (2005a) also found significant differences among populations for spring frost damage under field conditions. In the present study, population differences were significant for spring damage and field traits $(p<0.001)$, and for autumn damage traits $(p<0.01)$.
Other authors have also found significant differences among populations of different temperate species for injury traits in different seasons in Fraxinus americana L. (Alexander et al., 1984), Alnus rubra Bong. (Cannell et al., 1987), Q. petraea (Deans and Harvey, 1996; Jensen and Deans, 2004) and in P. trichocarpa (McCamant and Black, 2000) and for other cold adaptation traits, such as timing of phenological events in Q. robur L. (Jensen and Deans, 2004), and in J. regia L. (Díaz et al., 2006).

The present results indicate that genetic variation was always higher and more significant among populations than within populations, insomuch as genetic variation within populations was only found to be significant for the field traits $(p<0.01)$ and for the spring damage traits in bud tissue $(p<0.05)$. This may indicate that there is no variation within populations for autumn frost damage and for spring frost damage in stem tissue, and some variation for spring frost damage 
Table VI. Pearson's correlation coefficients between the field and damage traits and the geoclimatic parameters at origin.

\begin{tabular}{|c|c|c|c|c|c|c|c|c|c|c|c|c|c|c|c|c|}
\hline \multirow{2}{*}{ Geoclimatic parameters $^{c}$} & \multicolumn{4}{|c|}{ Field traits ${ }^{\mathrm{a}}$} & \multicolumn{12}{|c|}{ Damage traits ${ }^{b}$} \\
\hline & BB06 & & LF06 & & SD1 & & TB1 & & DBP1 & & SD2 & & TB2 & & DBP2 & \\
\hline \multicolumn{17}{|l|}{ All populations $(N=6)$} \\
\hline A & 0.91 & $*$ & & & 0.91 & $*$ & 0.90 & $*$ & 0.91 & $*$ & & & & & & \\
\hline $\mathrm{PE}$ & & & & & & & -0.82 & $*$ & -0.86 & $*$ & & & & & & \\
\hline TMMC & 0.84 & $*$ & & & 0.90 & $*$ & 0.87 & $*$ & 0.90 & $*$ & & & & & & \\
\hline AMT & & & 0.92 & $*$ & & & & & & & & & 0.96 & $* *$ & 0.81 & $*$ \\
\hline \multicolumn{17}{|c|}{ Four northern populations $(N=4)$} \\
\hline TMMF & & & & & & & & & & & & & -0.99 & $* *$ & -0.96 & $*$ \\
\hline ND0S & 1.00 & $* * *$ & 0.95 & $*$ & 0.98 & $*$ & 0.98 & $*$ & 0.96 & $*$ & 0.99 & $* *$ & & & & \\
\hline ND0A & 0.98 & $*$ & & & 0.97 & $*$ & & & & & 0.99 & $* *$ & & & & \\
\hline
\end{tabular}

${ }^{a}$ BB06, Bud burst in spring 2006; LF06, Leaf fall in autumn 2006.

${ }^{\mathrm{b}}$ SD1 and SD2: Spring and autumn stem damage, respectively; TB1 and TB2: Spring and autumn damage on terminal bud, respectively; DBP1 and DBP2: Spring and autumn damage on lateral buds (in percentage), respectively.

${ }^{\mathrm{c}}$ A: drought index; PE: min. monthly summer precipitation; TMMC: mean of max. temp. in month with highest mean; AMT: absolute maximum temp.; TMMF: mean of min. temp. in month with lowest mean; ND0S and ND0A: no. days with $T<0{ }^{\circ} \mathrm{C}$ in spring and in autumn, respectively.

Significance levels. *** $P<0.001 ; * * P<0.01 ; * P<0.05$.
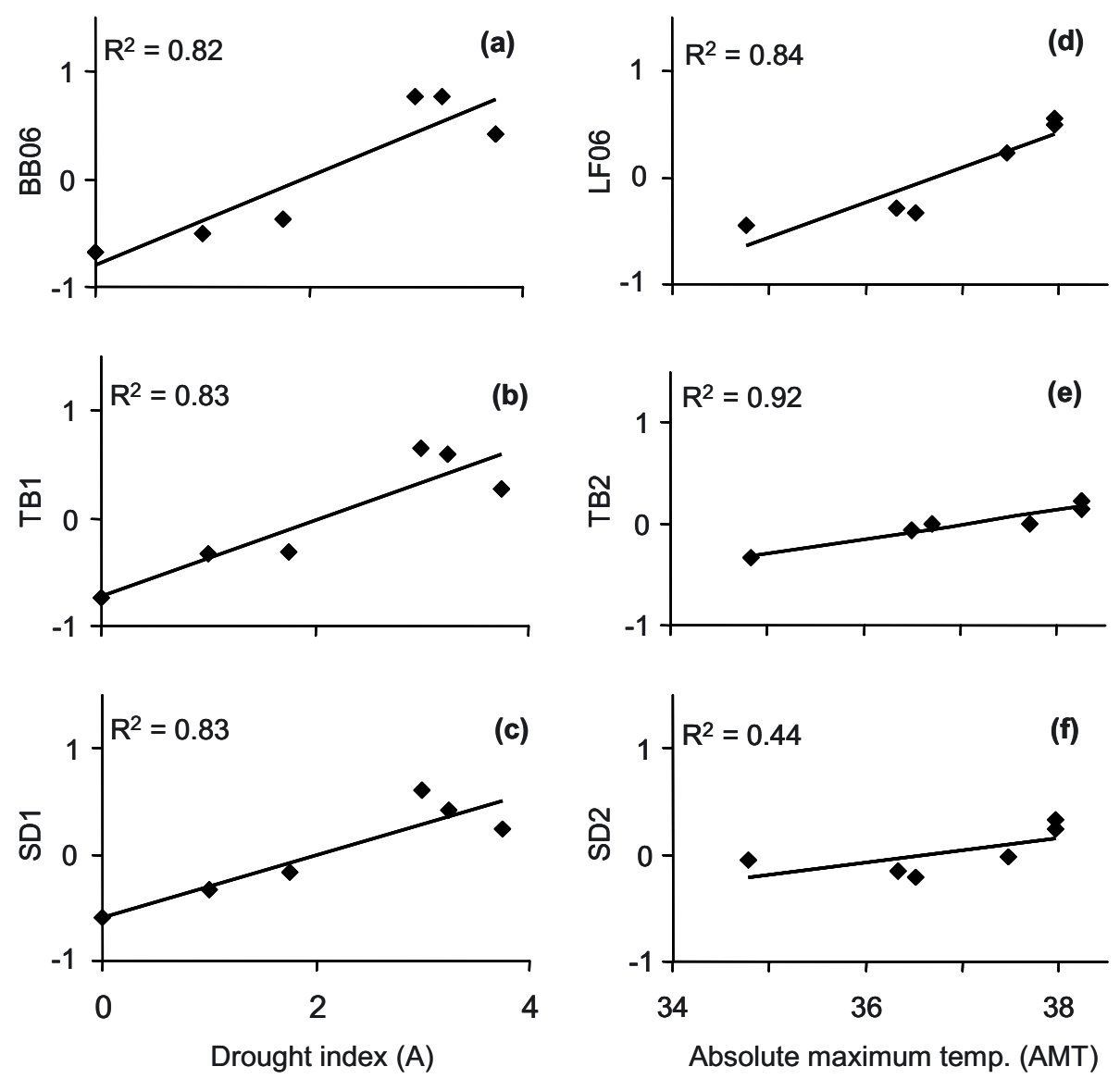

Figure 4. Relationships between different field and damage traits (Lsmeans population data) and some parameters at origin. $N=6$. (BB06 and LF06, bud burst and leaf fall in 2006; TB1 and TB2, terminal bud damage in spring and autumn; SD1 and SD2, stem damage in spring and autumn). 

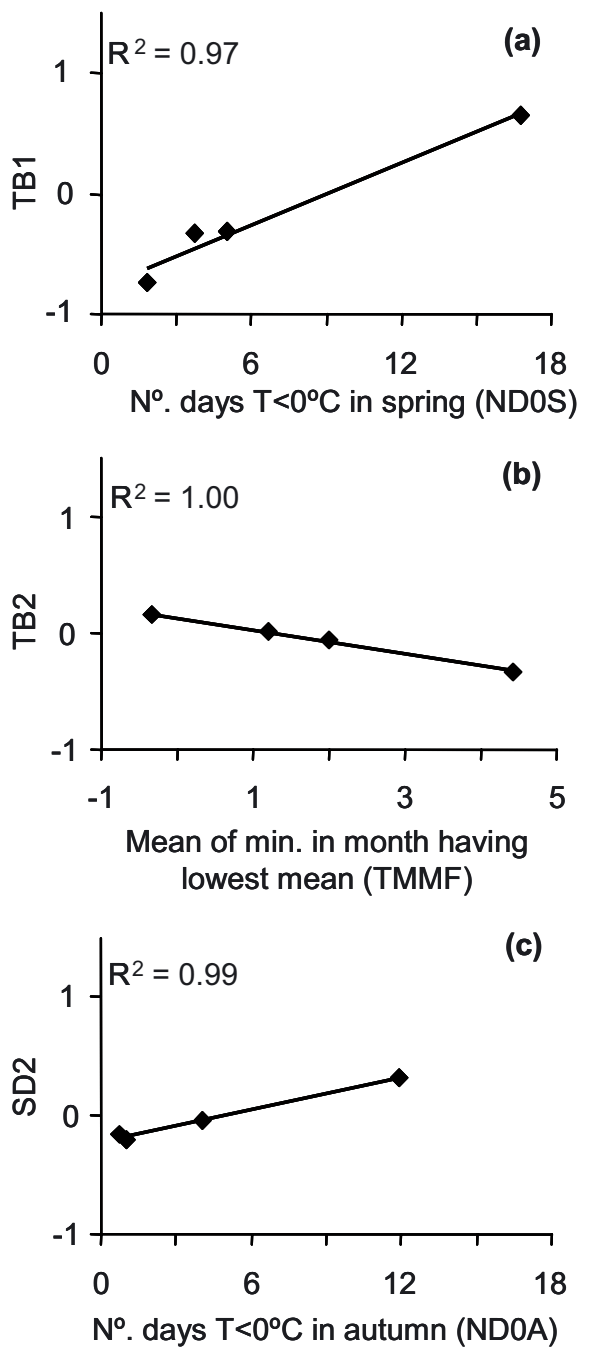

Figure 5. Relationships between different field and damage traits (Lsmeans population data) and some parameters at origin for the northern populations. $N=4$. (TB1 and TB2, terminal bud damage in spring and autumn; SD2, stem damage in autumn.)

in bud tissue. Fernández-López et al. (2005a), also found significant variation among populations of Spanish wild chestnut following natural spring frosts that occurred in two Spanish provenance tests, although the within-population variation was not assessed. Other studies have revealed variation within populations for cold hardiness in other species such as Picea abies L. (Johnsen and Skrøppa, 2000), Pinus monticola Dougl. Ex D. Don. (Thomas and Lester, 1992) and for Eucalyptus regnans F. Muell (Wilcox et al., 1980).

Cold adaptation traits are generally under strong natural selection. Nonetheless, high levels of genetic variation usually persist within populations (Howe et al., 2003). For wild chestnut, the principal effect of directional selection resulting from extreme environmental conditions, together with low gene flow among populations, is a reduction in genetic variation within populations, as well as high differentiation among populations (Eiga and Sakai, 1984; Stern and Roche, 1974).
Chestnut pollination is mainly entomophilous (Manino et al., 1991; Oliveira et al., 2001), and this species has large, sticky pollen, which may reduce gene flow among populations due to poor ability of pollen to be moved by wind (Ferrazzini et al., 2007). We thus suggest that the presumed low gene flow may lead to reduced genetic variation within populations.

It may be argued that the small number of families (5-8) in each population is too low for testing the presence or absence of family variation within populations. However, we think the sampling was sufficient in order to conclude that the mean variation within these six populations is fairly low, although larger samples would be required to establish whether some of the non-significant components shown in Tables II and V are really significant. Highly significant differences within populations were found in an experiment involving susceptibility to Phytophthora cinnamomi Rands, conducted on material from the same families and individuals as the present frost hardiness study (Miranda-Fontaíña and Fernández-López, 2006). Nevertheless, we suggest further studies with larger sample sizes, both within and among populations, in order to estimate more accurately the size of the variance components relative to the difference among populations, especially if a breeding programme for wild chestnut is carried out in northern Spain. The potential for genetic change as an evolutionary response to climatic warming may be limited, especially if late spring frosts and early autumn frosts become more severe and occur more frequently in the future. New breeding populations for chestnuts could be developed by considering differences among populations. Knowledge of intra-population differences will also be important for selecting for increasing cold hardiness and for breeding zone delineation. However, the evolutionary potential has been demonstrated for other traits such as drought tolerance, measured by carbon isotope discrimination (Pliura and Eriksson, 2002) or by phenological traits (Fernández-López et al., 2005b).

An understanding of the genetic programmes that control the mechanisms of frost tolerance may be of help in both breeding and gene conservation. These types of traits are mainly controlled by multiple genes with small effects (Howe et al., 2003). Transcription factors involved in cold acclimation (e.g., CBF/DREB1) are being studied in Populus, as well as genes that may directly confer cold hardiness, including dehydrins in Prunus, Betula and Picea (reviewed in Howe et al., 2003). The close correlation between bud phenology and frost hardiness may indicate that these two traits are controlled by overlapping genes. This occurs in some species, such as P. menziesii, in which three QTL (quantitative trait loci) for spring cold hardiness were mapped at the same locations as QTL for spring bud burst (Jermstad et al., 2001). Although timing of bud burst and leaf fall are important for spring and autumn frost tolerance, there must be other genetic factors involved, as reported for other species (Deans and Harvey, 1996; Jensen and Deans, 2004; Liepe, 1993). This may explain why differences among populations remained highly significant and large following a covariate analysis with bud burst and leaf fall as covariates for the spring and autumn frost injury, respectively (compare Figs. 2 and 3, and Tabs. II and $\mathrm{V}$ ). The present results indicate that we cannot rely only 
on phenological traits when assessing differences in frost hardiness in chestnut breeding populations. Direct testing by the use of controlled freezing is recommended.

Clinal variation is interpreted as being the product of natural selection under gradually changing environmental conditions (Morgenstern, 1996). Several authors have found geographical clines for frost resistance of different species (Deans and Harvey, 1995, 1996; Jensen and Deans, 2004; Liepe, 1993). Flint (1972) observed a geographical cline, related to latitude, for cold hardiness of $Q$. rubra in a study in which the latitude of origin was highly correlated with the average annual minimum temperature of origin. In the present study, a climatic cline rather than a geographical cline was observed. The climatic patterns were related to drought when tolerance to spring frosts was considered, and to maximum temperatures in summer for autumn frosts. Gradients in summer precipitation also revealed clines in susceptibility to frost injury in the autumn for P. menziesii (Joly et al., 1989). A different pattern was observed as regards the four northern populations $(1,2,5$ and 6). In this case, the traits were related to frost parameters. The observed patterns of variation indicate that natural selection has shaped the present structure of wild chestnut Spanish populations, as Howe et al. (2003) have pointed out for other species. Both drought and frosts are involved in natural selection (Fernández-López et al., 2005a). The present results show that when considering the entire range of distribution of chestnut in Spain, drought is more important than cold in determining traits related to growth and phenology (as reported by Fernández-López et al., 2005a), and also for shaping the variation in frost tolerance. For other species, such as $Q$. rubra, cold has been reported as the most important climatic factor that has shaped the structure of the species (Flint, 1972). In the south, however, the trees must match their growth to the period when water is available, which is confined to spring and very early summer. In summer and early autumn, bud set and leaf fall occur quite early, so that transpiration during dry weather is reduced. Later in the autumn, the trees do not need to be very tolerant to frost because of the low risk of frost in southern areas. This may explain why, in the present study, the southern populations shed their leaves earlier in autumn than the other populations, but are still the least frost tolerant. Southern populations (3 and 4) are therefore adapted to drought, but not to frosts, which is why they start and cease growth earlier, but are more susceptible to spring and autumn frosts. In northern Spain, however, it appears that spring and autumn frosts are the most important factors. Thus, although northern populations are not so well adapted to drought because of the humid coastal climate in these areas, they are better adapted to spring and autumn frosts, so that bud burst occurs later, and autumn frost tolerance develops rapidly and safely after leaf fall in the autumn.

Genotype $\times$ environment interaction can alter the ranking of the genetic entries from one environment to another (Skrøppa, 1984). We have only worked with material from a provenanceprogeny test planted in northwestern Spain, where the climatic conditions are quite similar to those under which populations 5 and 6 grow (the most frost tolerant populations) and therefore do not have any information about possible $\mathrm{G} \times \mathrm{E}$ interactions.
Future studies with material planted at several sites would be of interest for investigating $\mathrm{G} \times \mathrm{E}$ interactions in wild chestnut.

Correlations between different tissues in spring were strong and highly significant, but those in autumn were not. The lack of correlation found for autumn frost tolerance was mainly due to two northern populations, 1 and 5. Population 1 has the most tolerant buds but less tolerant stem tissue, while population 5 expresses the most tolerant stem tissue but less hardy bud tissue. Thus, evaluation of only bud tissue damage in field or controlled freezing tests may be inadequate for assessing the overall hardiness of populations. Moreover, dead buds may not fully reflect the survival capability of the plant, while stem tissue damage is probably more closely related to actual mortality (Jensen and Deans, 2004). The lack of correlation between bud and stem tissue damage in autumn may indicate that frost tolerance is controlled by different sets of genes or influenced differently by the same set of genes in different tissues.

\section{CONCLUSIONS}

Considerable variation among populations was observed for phenological and frost damage traits in Spanish wild chestnut. However, variation within populations was only observed for some of the studied traits. Differences among populations followed two clines: one related to drought and the other to frost. These results are consistent with those of previous studies and indicate that drought is the most important selective force that affects the entire range of distribution of Spanish wild chestnut, while frost appears to be the most important factor in the northern distribution.

The results also indicate the importance of carrying out controlled freezing tests to detect susceptibility to spring or autumn frost in chestnut, since phenological traits are not good predictors of frost damage. When freeze testing is done during spring, evaluation of just one trait, e.g. terminal bud damage, percentage of dead lateral buds or stem damage, should be sufficient for predicting the actual damage during spring. However, at least two damage traits (one in stem and one in bud tissue) should be evaluated in autumn, since it appears that in autumn, the genetic entries are classified differently depending on the damage traits considered for different tissues.

Acknowledgements: The authors are grateful to Antonio González and Eva Alonso for their assistance in assessment of the frost assays. R.D. was funded by an 'INIA-CCAA' postdoctoral fellowship. The study was financed by the EU 092 CASTANEAREG project (INTERREG III programme).

\section{REFERENCES}

Aira-Rodríguez M.J. and Ramil-Rego P., 1995. Paleobotanical data from Northern Portugal (Baixo Minho) from pollen analysis and fossil seeds. Lagascalia 18: 25-38.

Aitken S.N. and Adams W.T., 1996. Genetics of fall and winter cold hardiness of coastal Douglas-fir in Oregon. Can. J. For. Res. 26: 18281837.

Aldrete A., Mexal J.G., and Burr K.E., 2008. Seedling cold hardiness, bud set, and bud break in nine provenances of Pinus greggii Engelm. For. Ecol. Manage. 255: 3672-3676. 
Alexander N.L., Flint H.L., and Hammer P.A., 1984. Variation in cold hardiness of Fraxinus americana stem tissue according to geographic origin. Ecology 65: 1087-1092.

Allué J.L., 1990. Atlas fitoclimático de España. Taxonomías, INIA. Ministerio de Agricultura, Pesca y Alimentación, Madrid, 221 p.

Baliuckas V., Ekberg I., Eriksson G., and Norell L., 1999. Genetic variation among and within populations of four Swedish hardwood species assessed in a nursery trial. Silvae Genet. 48: 17-24.

Calkins J.B. and Swanson B.T., 1990. The distinction between living and dead plant-tissue viability tests in cold hardiness research. Cryobiology 27: 194-211.

Cannell M.G.R., Murray M.B., and Sheppard L.J., 1987. Frost hardiness of red alder (Alnus rubra) provenances in Britain. Forestry 60: 57-67.

Deans J.D. and Harvey F.J., 1995. Phenologies of sixteen European provenances of sessile oak growing in Scotland. Forestry 68: 265273.

Deans J.D. and Harvey F.J., 1996. Frost hardiness of 16 European provenances of sessile oak growing in Scotland. Forestry 69: 5-11.

Díaz R., Bauone N., Ninot A., Fernández-López J., and Aletà N., 2006. Performance differences and genetic parameters for four local Spanish populations. Acta Hort. 705: 103-108.

Eiga S. and Sakai A., 1984. Altitudinal variation in freezing resistance of saghalien fir (Abies sachalinensis). Can. J. Bot. 62: 156-160.

Eriksson G. and Ekberg I., 2001. An Introduction to Forest Genetics, Swedish University of Agricultural Sciences, Uppsala, $166 \mathrm{p}$.

Fernández-López J., Zas R., Blanco-Silva R., and Díaz R., 2005a. Geographic differentiation in adaptative traits of wild chestnut Spanish populations (Castanea sativa Miller). Investigación Agraria: Sistemas y Recursos Forestales 14: 13-26.

Fernández-López J., Zas R., Díaz R., Villani F., Cherubini M., Aravanopoulos F.A., Alizoti P., Eriksson G., Botta R., and Mellano M.G., 2005b. Geographic variability among extreme European wild chestnut populations. Acta Hort. 693: 181-186.

Fernandez M., Marcos C., Tapias R., Ruiz F., and Lopez G., 2007. Nursery fertilisation affects the frost-tolerance and plant quality of Eucalyptus globulus Labill. cuttings. Ann. For. Sci. 64: 865-873.

Ferrazzini D., Monteleone I., and Belletti P., 2007. Genetic variability and divergence among Italian populations of common ash (Fraxinus excelsior L.). Ann. For. Sci. 64: 159-168.

Fineschi S., Taurchini D., Villani F., and Vendramin G.G., 2000 Chloroplast DNA polymorphism reveals little geographical structure in Castanea sativa Mill. (Fagaceae) throughout southern European countries. Mol. Ecol. 9: 1495-1503.

Flint H.L., 1972. Cold hardiness of twigs of Quercus rubra L. as a function of geographic origin. Ecology 53: 1163-1170.

García-Antón M., Morla-Juaristi C., and Sainz-Ollero H., 1990. Consideraciones sobre la presencia de algunos vegetales relictos terciarios durante el cuaternario en la Península Ibérica. Bol. R. Soc. Esp. Hist. Nat. (Sec. Biol.) 86: 95-105.

Hanninen H., Hakkinen R., Hari P., and Koski V., 1990. Timing of growth cessation in relation to climatic adaptation of northern woody plants. Tree Physiol. 6: 29-39.

Howe G.T., Aitken S.N., Neale D.B., Jermstad K.D., Wheeler N.C., and Chen T.H.H., 2003. From genotype to phenotype: unraveling the complexities of cold adaptation in forest trees. Can. J. Bot. 81: 12471266.

Jensen J.S. and Deans J.D., 2004. Late autumn frost resistance of twelve north European provenances of Quercus species. Scand. J. For. Res. 19: 390-399.

Jermstad K.D., Bassoni D.L., Jech K.S., Wheeler N.C., and Neale D.B., 2001. Mapping of quantitative trait loci controlling adaptive traits in coastal Douglas fir. I. Timing of vegetative bud flush. Theor. Appl. Genet. 102: 1142-1151.

Johnsen Ø., 1989. Freeze-testing young Picea abies plants. Scand. J. For. Res. 4: 351-367.

Johnsen Ø., Fossdal C.G., Nagy N., Molmann J., Daehlen O.G., and Skrøppa T., 2005. Climatic adaptation in Picea abies progenies is affected by the temperature during zygotic embryogenesis and seed maturation. Plant Cell Environ. 28: 1090-1102.
Johnsen Ø. and Skrøppa T., 2000. Provenances and families show different patterns of relationship between bud set and frost hardiness in Picea abies. Can. J. For. Res. 30: 1858-1866.

Joly R.J., Adams W.T., and Stafford S.G., 1989. Phenological and morphological responses of mesic and dry site sources of coastal Douglas-fir to water deficit. For. Sci. 35: 987-1005.

Krebs P., Conedera M., Pradella M., Torriani D., Felber M., and Tinner W., 2004. Quaternary refugia of the sweet chestnut (Castanea sativa Mill.): an expended palynological approach. Veget. Hist. Archeobot. 13: $145-160$.

Lauteri M., Pliura A., Monteverdi M.C., Brugnoli E., Villani F., and Eriksson G., 2004. Genetic variation in carbon isotope discrimination in six European populations of Castanea sativa Mill. originating from contrasting localities. J. Evol. Biol. 17: 1286-1296.

Liepe K., 1993. Growth-chamber trial on frost hardiness and field trial on flushing of sessile oak (Quercus petraea Liebl). Ann. Sci. For. 50 (Suppl.): 208s-214s.

Linkosalo T., Hakkinen R., and Hanninen H., 2006. Models of the spring phenology of boreal and temperate trees: is there something missing? Tree Physiol. 26: 1165-1172.

Lynch M. and Walsh B., 1998. Genetics and analysis of quantitative traits, Sinauer Associates Inc., Sunderland, 979 p.

Manino A., Patetta A., and Marletto F., 1991. Investigations on chestnut pollination. Acta Hortic. 288: 335-339.

McCamant T. and Black R.A., 2000. Cold hardiness in coastal, montane, and inland populations of Populus trichocarpa. Can. J. For. Res. 30: 91-99.

Miranda-Fontaíña M.E. and Fernández-López J., 2006. Genetic variation in susceptibility to Phytophthora cinnamomi in Spanish natural chestnut populations. In: Population genetics and genomics of forest trees: from gene function to evolutionary dynamics and Conservation, IUFRO, Alcalá de Henares, Madrid (Spain), 214 p.

Morgenstern E.K., 1996. Geographic variation in forest trees: Genetic basis and application of knowledge in silviculture, UBC Press, Vancouver, $209 \mathrm{p}$.

Oliveira D., Gomes A., Ilharco F.A., Manteigas A.M., Pinto J., and Ramalho J., 2001. Importance of insect pollinators for the production in the chestnut, Castanea sativa. Acta Hort. 561: 269-273.

Pliura A. and Eriksson G., 2002. Genetic variation in juvenile height and biomass of open-pollinated families of six Castanea sativa Mill. populations in a $2 \times 2$ factorial temperature $\mathrm{x}$ watering experiment. Silvae Genet. 51: 152-160.

Sakai A. and Larcher W., 1987. Frost survival of plants. Responses and adaptations to freezing stress, Springer-Verlag, New York, $252 \mathrm{p}$.

SAS, 1999. Getting started with the SAS System, Version 8, SAS Institute Inc., Cary, NC, $90 \mathrm{p}$.

Saxe H., Cannell M.G.R., Johnsen B., Ryan M.G., and Vourlitis G., 2001. Tree and forest functioning in response to global warming. New Phytol. 149: 369-399.

Skrøppa T., 1984. A critical evaluation of methods avaliable to estimate the genotype $\mathrm{x}$ environment interaction. Studia Forestalia Suecica 166: $3-14$.

Smithberg M.H. and Weiser C.J., 1968. Patterns of variation among climatic races of red-osier dogwood. Ecology 49: 495-505.

Squillace A.E., 1974. Average genetic correlations among offspring from open-pollinated forest trees. Silvae Genet. 23: 149-156.

Stern K. and Roche L., 1974. Genetics of forest ecosystems, Springer Verlag, $330 \mathrm{p}$.

Thomas B.R. and Lester D.T., 1992. An examination of regional, provenance, and family variation in cold hardiness of Pinus monticola. Can. J. For. Res. 22: 1917-1921.

Tsarouhas V., Kenney W.A., and Zsuffa L., 2000. Application of two electrical methods for the rapid assessment of freezing resistance in Salix eriocephala. Biomass Bioenergy 19: 165-175.

Weiser C.J., 1970. Cold resistance and injury in woody plants. Science 169: 1269-1278.

Wilcox M.D., Faulds T., Vincent T.G., and Poole B.R., 1980. Genetic variation in frost tolerance among open-pollinated families of Eucalyptus regnans Muell F. Aust. For. Res. 10: 169-184. 